\title{
PENGARUH CAR, LDR DAN BOPO TERHADAP ROA PERUSAHAAN PERBANKAN KONVENSIONAL DI BEI
}

\author{
AGUS BOICE HUTAGALUNG \\ MUSLIMIN \\ ENKI P. NAINGGOLAN \\ Program Studi Manajemen, Fakultas Ekonomi, Universitas Tadulako \\ email:boygalung16@gmail.com
}

\begin{abstract}
This study aims to determine the effect of Capital Adequacy Ratio, Loan to Deposit Ratio, and BOPO simultaneously and partially on Return On Assets of Conventional Banking Companies in the Indonesia Stock Exchange. The population in this study were 42 conventional banking companies listed on the Indonesia Stock Exchange. Sampling was carried out by purposive sampling method with the aim of obtaining samples in accordance with the research objectives and from the number of samples taken as many as 11 companies. The analytical method used in this study is panel data regression analysis.

The results of this study indicate that during the period 2012-2016 (1) simultaneously CAR, LDR and $B O P O$ had a significant effect on ROA in conventional banking companies listed on the IDX, (2) CAR partially had no significant effect on ROA, (3) LDR partially no significant effect on ROA, (4) BOPO partially has a significant effect on ROA of conventional banking companies on the Indonesia Stock Exchange.
\end{abstract}

Keywords: $C A R, L D R, B O P O, R O A$

\begin{abstract}
Abstrak
Penelitian ini bertujuan untuk mengetahui pengaruh Capital Adequacy Ratio, Loan to Deposit Ratio, dan BOPO secara serempak dan parsial terhadap Return On Assets Perusahaan Perbankan Konvensional di Bursa Efek Indonesia. Populasi dalam penelitian ini sebanyak 42 perusahaan perbankan konvensional yang terdaftar di Bursa Efek Indonesia. Pengambilan sampel dilakukan dengan metode purposive sampling dengan tujuan untuk mendapatkan sampel yang sesuai dengan tujuan penelitian dan dari jumlah yang ada maka diambil sampel sebanyak 11 perusahaan. Metode analisis yang digunakan dalam penelitian ini adalah analisis regresi data panel.

Hasil dari penelitian ini menunjukkan bahwa selama periode 2012-2016 (1) secara simultan CAR, LDR dan BOPO berpengaruh signifikan terhadap ROA pada perusahaan perbankan konvensional yang terdaftar di BEI, (2) CAR secara parsial tidak berpengaruh signifikan terhadap ROA, (3) LDR secara parsial tidak berpengaruh signifikan terhadap ROA, (4) BOPO secara parsial berpengaruh signifikan terhadap ROA perusahaan perbankan konvensional di Bursa Efek Indonesia.
\end{abstract}

Kata kunci: CAR, LDR, BOPO, ROA

\section{PENDAHULUAN}

Industri perbankan di Indonesia mempunyai peranan penting di dalam perekonomian negara sebagai lembaga perantara keuangan. Perbankan berfungsi sebagai lembaga yang berperan untuk menghimpun dan menyalurkan dana masyarakat. Kegiatan bank harus berjalan secara efisien pada skala makro maupun mikro. Dana hasil mobilitas dialokasikan ke berbagai ragam sektor ekonomi dan keseluruhan area yang membutuhkan, secara cepat dan tepat.

Sektor perbankan bertindak sebagai urat nadi perdagangan yang bertujuan untuk menyediakan segala macam kebutuhan pembiayaan dan peminjaman. Bank memberikan kontribusi besar terhadap perekonomian suatu negara.Bank sebagai lembaga intermediasi mempunyai peranan sebagai jalur 
pembiayaan, penyimpanan dan peminjaman sehingga pada akhirnya mensejahterakan masyarakat.Maka dari itu bank dipaksa untuk menjadi lebih kompetitif dan menerapkan sistem penilaian tingkat kesehatan bank.

Persaingan antarbank dalam menghimpun dana dari masyarakat dan menyalurkannya kembali dalam bentuk kredit, dalam prakteknya banyak yang menyimpang dari aturan yang berlaku dalam industri perbankan seperti tidak mengindahkan prinsip kehati-hatian bank (prudential banking) dengan memberikan kredit tak terbatas pada nasabah satu grup dengan perbankan tersebut, sehingga deposan dan investor dirugikan serta berdampak pada perekonomian negara, misalnya kasus Bank Century.

Kesehatan bank dapat diketahui dengan menganalisis kekuatan maupun kelemahan suatu bank serta mengevaluasi kinerja bank dan memprediksi kinerja bank ke depannya.Kinerja bank yang baik memiliki tingkat kepercayaan masyarakat terhadap bank yang semakin meningkat dan berpengaruh terhadap profitabilitas dan sebaliknya apabila kinerja bank menurun, maka tingkat kepercayaan nasabah berkurang sehingga berdampak pada profitabilitas yang menurun.

Kondisi kesehatan bank di Indonesia perlu diketahui dalam menjalankan operasional perusahaannya. Pembinaan dan pengawasan bank menurut pasal 29 ayat 2 Undang-undang Republik Indonesia No. 10 Tahun 1998, yaitu: bank wajib memelihara tingkat kesehatan bank sesuai dengan ketentuan rasio kecukupan modal, kualitas aset, kualitas manajemen, likuiditas, rentabilitas, solvabilitas, dan aspek lain yang berhubungan dengan usaha bank, dan wajib melakukan kegiatan usaha sesuai dengan prinsip kehatihatian.

Kinerja suatu perbankan dilihat dari profitabilitasnya, dimana bank dalam melakukan kegiatan operasionalnya bertujuan untuk memaksimalkan profitabilitasnya.Profitabilitas merupakan tolok ukur kinerja perbankan. Berikut ini adalah tabel kinerja keuangan bank konvensional di Bursa Efek Indonesia dari tahun 2012 sampai dengan tahun 2016 yang dilihat dari Return On Assets, Capital Adequacy Ratio, Loan to Deposit Ratio dan Biaya Operasional Pendapatan Operasional.

Tabel 1

Kinerja Bank Konvensional (\%)

\begin{tabular}{llllll}
\hline No & Tahun & ROA & CAR & LDR & BOPO \\
\hline 1 & 2012 & 3,11 & 17,43 & 83,58 & 74,10 \\
2 & 2013 & 3,08 & 18,13 & 89,70 & 74,08 \\
3 & 2014 & 2,85 & 19,57 & 89,42 & 76,29 \\
4 & 2015 & 2,32 & 21,39 & 92,11 & 81,49 \\
5 & 2016 & 2,23 & 22,93 & 90,70 & 82,22 \\
\hline
\end{tabular}

Tabel di atas menunjukkan Kinerja Bank Konvensional dari tahun 2012 sampai tahun 2016.Terlihat bahwa profitabilitas yang ditunjukkan Rasio ROA menurun dari tahun 2012 sampai dengan tahun 2016.Rasio CAR pada tahun 2012 sampai 2016 mengalami peningkatan. Tahun 2012 sampai 2013 LDR meningkat sebesar 6,12 persen sedangkan pada tahun berikutnya yakni tahun 2014 sampai tahun 2015 mengalami penurunan sebesar 0,46 persen bahkan di tahun 2016 menurun menjadi 90,70\%. Pada rasio BOPO tahun 2012 sampai 2013 mengalami penurunan nilai BOPO sebesar 0,02 persen kemudian pada tahun 2014 sampai 2015 naik 4,86 persen kemudian naik di tahun 2016 menjadi 82,22\%. Faktor penentu 
profitabilitas bank dapat dilihat dari faktor internalnya yang meliputi kecukupan modal, likuiditas, dan efisiensi operasional.

Kepercayaan nasabah bisa dicapai suatu bank jika bank yang beroperasi dengan baik harus didasari dengan permodalan yang baik pula.Capital Adequacy Ratio menunjukkan kemampuan manajemen bank untuk mengawasi dan mengontrol risiko yang terjadi, yang bisa mempengaruhi besarnya modal bank. Bank yang memiliki modal yang memadai dapat melakukan kegiatan operasionalnya dengan efisien, dan akan memberikan keuntungan pada bank tersebut.

Loan to Deposit merupakan salah satu alat ukur kesehatan suatu bank yang dinilai dari laporan keuangan perusahaan bank. Likuiditas perbankan yang berarti kemampuan bank dalam membayar hutang kepada nasabah dalam bentuk simpanan giro, tabungan dan deposito ketika ditagih oleh nasabah penghimpun dana, serta mampu memenuhi pemberian kredit kepada nasabah yang layak untuk dibiayai. Rasio likuiditas dikatakan sehat apabila nilainya sebesar 200\%, jika nilainya berada di bawah 200\% maka dianggap kurang baik. Berapapun nilai persentase kesehatan suatu bank, yang terpenting adalah bank mampu memenuhi kewajiban jangka pendeknya.Likuiditas merupakan masalah yang sering dihadapi dunia perbankan seperti pada masa krisis keuangan global yang terjadi di Amerika Serikat pada tahun 2008.

Rasio BOPO adalah rasio perbandingan antara biaya operasional dengan pendapatan operasional. Bank sebagai perantara menghimpun dana dan menyalurkan dana masyarakat, maka biaya dan pendapatan operasional bank terdominasi oleh biaya bunga dan hasil bunga. Setiap peningkatan biaya operasional akan berakibat pada berkurangnya laba sebelum pajak yang pada akhirnya akan menurunkan laba atau profitabilitas bank yang bersangkutan (Dendawijaya, 2003).

Berdasarkan latar belakang yang telah diuraikan di atas, maka rumusan masalah pada penelitian ini adalah sebagai berikut: (1) Bagaimanakah CAR, LDR, BOPO dan ROA pada Perusahaan perbankan Konvensional di Bursa Efek Indonesia? (2) Apakah CAR, LDR dan BOPO bersama-sama berpengaruh terhadap ROA pada Perusahaan Perbankan Konvensional di Bursa Efek Indonesia? (3) Apakah CAR secara parsial berpengaruh terhadap ROA pada Perusahaan Perbankan Konvensional di Bursa Efek Indonesia? (4) Apakah LDR secara parsial berpengaruh terhadap ROA pada Perusahaan Perbankan Konvensional di Bursa Efek Indonesia? (5) Apakah BOPO secara parsial berpengaruh terhadap ROA pada Perusahaan Perbankan Konvensional di Bursa Efek Indonesia?. Tujuan yang ingin dicapai dalam penelitian ini adalah untuk: (1) Melihat gambaran secara deskriptif CAR, LDR, BOPO dan ROA Perusahaan Perbankan Konvensional di BEI. (2) Mengetahui pengaruh secara simultan CAR, LDR, dan BOPO terhadap ROA pada perusahaan Perbankan Konvensional di BEI. (3) Mengetahui pengaruh CAR secara parsial terhadap ROA pada perusahaan Perbankan Konvensional di BEI. (4) Mengetahui pengaruh LDR secara parsial terhadap ROA pada perusahaan Perbankan Konvensional di BEI. (5) Mengetahui pengaruh BOPO secara parsial terhadap ROA pada perusahaan Perbankan Konvensional di BEI.

\section{KAJIAN LITERATUR}

Pengertian Bank menurut UU RI No. 10 tanggal 10 November 1998 tentang perbankan adalah Bank merupakan badan usaha yang menghimpun dana dari masyarakat dalam bentuk simpanan dan menyalurkannya kepada masyarakat dalam bentuk kredit atau bentuk-bentuk lainnya dalam rangka meningkatkan taraf hidup rakyat banyak (Kasmir, 2008:12). 
Menurut Fahmi (2011:2), kinerja keuangan merupakan analisis yang dilakukan untuk melihat sejauh mana suatu perusahaan telah melaksanakan dengan menggunakan aturan-aturan pelaksanaan keuangan secara baik dan benar.Penilaian kinerja keuangan bank dapat dilakukan dengan menganalisis laporan keuangan. Berdasarkan Peraturan Bank Indonesia Nomor: 14/14/PBI/2012 Tentang Transparansi dan Publikasi Laporan Bank, Bank wajib menyusun dan menyajikan laporan keuangan dengan bentuk dan cakupan sebagaimana ditetapkan dalam Peraturan Bank Indonesia ini, yang terdiri dari: (1) Laporan Tahunan, (2) Laporan Keuangan Publikasi Triwulan, (3) Laporan Keuangan Publikasi Bulanan, (4) Laporan Keuangan Konsolidasi dan (5) Laporan Publikasi Lain.

Menurut Ikatan Akuntan Indonesia (2009:1), laporan Keuangan meliputi bagian dari proses laporan keuangan. Laporan Keuangan yang lengkap biasanya meliputi neraca, laporan laba rugi, laporan perubahan ekuitas, laporan perubahan posisi keuangan (yang dapat disajikan dalam berbagai cara misalnya, sebagai laporan arus kas/laporan arus dana), catatan dan laporan lain serta materi penjelasan yang merupakan bagian integral dari laporan keuangan.

Rasio Menurut Fahmi (2012:44) adalah perbandingan yang dapat memberikan gambaran relatif tentang kondisi keuangan dan prestasi perusahaan bisa juga secara sederhana disebut sebagai perbandingan jumlah dengan jumlah lainnya itulah dilihat perbandingannya dengan harapan nantinya akan ditemukan jawaban yang selanjutnya dijadikan bahan kajian untuk dianalisis dan diputuskan.Rasio keuangan adalah angka yang diperoleh dari hasil perbandingan dari satu pos laporan keuangan dengan pos lainnya yang mempunyai hubungan yang relevan dan signifikan.

Menurut Dendawijaya (2009:121) capital adequacy ratio (CAR) adalah rasio kinerja bank untuk mengukur kecukupan modal yang dimiliki bank untuk menunjang aktiva yang mengandung atau menghasilkan risiko, misalnya kredit yang diberikan.CAR menurut standar BIS (Bank for International Settlements) yang dianut oleh Bank Indonesia minimum sebesar 8\%. Jika kurang dari itu akan dikenakan sanksi oleh Bank Sentral. Bank dengan modal yang tinggi dianggap relatif lebih aman dibandingkan dengan bank modal yang rendah, hal ini disebabkan bank dengan modal yang tinggi biasanya memiliki kebutuhan yang lebih rendah dari pada pendanaan eksternal. Bank Indonesia menetapkan besarnya rasio CAR yaitu minimum 8 persen.

Tingkat modal yang tinggi akan meningkatkan cadangan kas yang dapat digunakan untuk memperluas kreditnya, sehingga tingkat solvabilitas yang tinggi akan membuka peluang yang lebih besar bagi bank untuk meningkatkan profitabilitasnya. Sebaliknya bank yang tingkat solvabilitasnya rendah akan mengurangi kemampuan bank untuk meningkatkan profitabilitasnya, bahkan dapat mengurangi kepercayaan masyarakat, sehingga akan berpengaruh buruk terhadap kelangsungan usahanya.

Rasio Likuiditas merupakan rasio untuk mengukur kemampuan bank dalam memenuhi kewajiban jangka pendeknya pada saat ditagih. Bank dapat membayar kembali pencairan dana deposannya pada saat ditagih serta dapat mencukupi permintaan kredit yang telah diajukan. Semakin besar rasio ini semakin likuid (Kasmir,2014:315).Sebuah perusahaan diwajibkan untuk mempertahankan likuiditasnya menjamin kelancaran operasi dalam memenuhi kewajibannya. Bank yang memiliki total aset besar, mempunyai kesempatan untuk menyalurkan kreditnya kepada pihak peminjam dalam jumlah yang lebih besar, sehingga memperoleh keuntungan yang tinggi. Bank Indonesia menetapkan besarnya rasio LDR yaitu 110 persen.

Tingginya rasio LDR mengindikasikan bahwa dana deposito dari masyarakat yang tertanam dalam pinjaman semakin besar. Semakin besarnya penyaluran kredit maka dalam kondisi yang normal akan 
menyebabkan laba yang meningkat. Laba ini berasal dari penerimaan bunga pinjaman dari kredit yang disalurkan. Tetapi jika bank mengurangi jumlah kredit yang telah dikucurkan (mengubah aktiva kredit menjadi aktiva yang kurang produktif), maka kemampuan bank untuk memperoleh penghasilan (terutama penghasilan yang berasal dari bunga pinjaman) akan turun. Penurunan ini akan berakibat menurunnya ROA.

Rasio BOPO digunakan untuk mengukur tingkat efisiensi dan kemampuan bank dalam melakukan kegiatan operasinya. Semakin besar BOPO maka akan semakin kecil atau menurun kinerja keuangan perbankan. Begitu juga sebaliknya, jika BOPO semakin kecil, maka dapat disimpulkan bahwa kinerja keuangan perbankan semakin meningkat atau membaik (Ambo,2013).Biaya operasional merupakan biaya yang dikeluarkan oleh pihak bank dalam menjalankan aktivitasnya sehari-hari meliputi: biaya gaji, biaya pemasaran, biaya bunga. Sedangkan pendapatan operasional merupakan pendapatan yang diterima oleh pihak bank yang diperoleh melalui penyaluran kredit dalam bentuk suku bunga. Bank Indonesia menetapkan besarnya rasio BOPO tidak melebihi 90 persen, apabila melebihi 90 persen, maka bank tersebut dikategorikan tidak efisien.

Peningkatan biaya operasional bank yang tidak diikuti dengan peningkatan pendapatan operasional akan berakibat berkurangnya laba bersih sehingga akan menurunkan profitabilitas (ROA). Tingginya biaya yang dikeluarkan dalam menghasilkan keuntungan yang dicapai perusahaan, maka akan mengakibatkan rendahnya efisiensi operasional bank dan selanjutnya berpengaruh terhadap tingkat profitabilitas yang semakin menurun. Tetapi jika penurunan biaya operasional bank diikuti dengan kenaikan pendapatan operasional, maka akan mempengaruhi pula kenaikan ROA.

ROA adalah perbandingan atau rasio laba sebelum pajak (earning before tax/EBT) selama 12 bulan terakhir terhadap rata-rata volume usaha dalam periode yang sama.ROA merupakan alat rasio keuangan sebagai indikator penilaian profitabilitas bank.ROA berfungsi mengukur efektifitas perusahaan dalam menghasilkan laba dengan memanfaatkan aktiva yang dimiliki. Semakin besar ROA yang dimiliki oleh sebuah perusahaan, semakin efisien penggunaan aktiva sehingga akan memperbesar laba. Laba yang besar akan menarik investor karena persuahaan memiliki tingkat kembalian yang semakin tinggi.standarROA yang ditetapkan bank indonesia adalah minimal 1,5\%. Maka disusun beberapa hipotesis penelitian sebagai berikut:

H1:CAR, LDR dan BOPO secara simultan berpengaruh signifikan terhadap Return on assets (ROA) pada perusahaan perbankan konvensional di BEI.

H2:Capital Adequacy Ratio (CAR) secara Parsial berpengaruh signifikan terhadap Return on assets (ROA) pada perusahaan perbankan konvensional di BEI.

H3:Loan to deposit ratio (LDR) secara Parsial berpengaruh signifikan terhadap Return on assets (ROA) pada perusahaan perbankan konvensional di BEI.

H4:Biaya Operasional Pendapatan Operasional secara Parsial berpengaruh signifikan terhadap Return on assets (ROA) pada perusahaan perbankan konvensional di BEI.

\section{METODE PENELITIAN}

Penelitian ini menggunakan metode deksriptif yang bersifat kuantitatif karena objek penelitian yang digunakan pada perusahaan dalam suatu industri dengan kurun waktu tertentu dengan mengumpulkan data dan informasi yang berkaitan dengan perusahaan dan disesuaikan dengan tujuan penelitian. Metode ini 
disebut metode kuantitatif karena data penelitian berupa angka-angka dan analisis menggunakan statistik (Sugiyono, 2011:7).

Teknik yang digunakan penulis dalam pengumpulan data adalah sebagai berikut:(1) Dokumentasi, yaitu pengumpulan data yang dilakukan dengan cara mengumpulkan dokumen-dokumen perusahaan seperti neraca, laporan laba rugi, dan struktur organisasi perusahaan yang dibutuhkan dalam penelitian ini.(2)Studi Pustaka, yaitu teknik pengumpulan data yang dilakukan dengan cara mengumpulkan dan mempelajari buku-buku, artikel, serta literatur lainnya, melalui situs Bursa Efek Indonesia, dan karyakarya ilmiah tulis yang dapat mendukung penelitian ini.

Berdasarkan permasalahan dan hipotesis yang akan diuji, jenis data yang digunakan dalam penelitian ini adalah data sekunder yaitu data yang diperoleh dari pihak lain dalam bentuk data yang sudah jadi atau berupa publikasi. Data sekunder adalah data yang telah dikumpulkan oleh lembaga pengumpul data dan dipublikasikan kepada masyarakat pengguna data (Kuncoro,2009:148). Data sekunder umumnya berupa bukti catatan atau laporan historis yang telah tersusun dalam arsip yang dipublikasikan dan tidak dipublikasikan, struktur organisasi, ketenagakerjaan dan laporan keuangan.

Populasi adalah kelompok elemen yang lengkap, yang biasanya berupa orang, objek, transaksi, atau kejadian di mana kita tertarik untuk mempelajarinya atau menjadi objek penelitian (Kuncoro,2009: 118).Populasi menurut Sugiyono (2011:80) merupakan generalisasi yang terdiri atas objek/subjek yang mempunyai kualitas dan karakteristik tertentu yang ditetapkan oleh peneliti untuk dipelajari dan kemudian ditarik kesimpulannya. Populasi dalam penelitian ini adalah seluruh perusahaan perbankan konvensional yang tedaftar di Bursa Efek Indonesia Tahun 2012-2016 yang ditunjukkan tabel 2:

Tabel 2

Populasi Bank Konvensional di Bursa Efek IndonesiaPeriode 2012-2016

\begin{tabular}{cll}
\hline No. & Kode & \multicolumn{1}{c}{ Nama Bank } \\
\hline 1 & AGRO & PT. BANK RAKYAT INDONESIA AGRONIAGA, TBK \\
2 & AGRS & PT. BANK AGRIS, TBK \\
3 & BABP & PT. BANK ICB BUMIPUTERA, TBK \\
4 & BACA & PT. BANK CAPITAL INDONESIA, TBK \\
5 & BAEK & PT. BANK EKONOMI RAHARJA, TBK \\
6 & BBCA & PT. BANK CENTRAL ASIA, TBK \\
7 & BBHI & PT. BANK HARDA INTERNASIONAL, TBK \\
8 & BBKP & PT. BANK BUKOPIN, TBK \\
9 & BBMD & PT. BANK MESTIKA DHARMA, TBK \\
10 & BBNI & PT. BANK NEGARA INDONESIA (PERSERO), TBK \\
11 & BBNP & PT. BANK NUSANTARA PARAHYANGAN, TBK \\
12 & BBRI & PT. BANK RAKYAT INDONESIA (PERSERO), TBK \\
13 & BBTN & PT. BANK TABUNGAN NEGARA (PERSERO), TBK \\
14 & BBYB & PT. BANK YUDHA BHAKTI, TBK \\
15 & BCIC & PT. BANK MUTIARA, TBK \\
16 & BDMN & PT. BANK DANAMON INDONESIA, TBK \\
17 & BEKS & PT. BANK PUNDI INDONESIA, TBK \\
18 & BINA & PT. BANK INA PERDANA, TBK \\
\hline
\end{tabular}




\begin{tabular}{lll}
\hline 19 & BJBR & PT. BANK PEMBANGUNAN DAERAH JAWA BARAT DAN \\
& & BANTEN, TBK (BANK BJB) \\
20 & BJTM & PT. BANK PEMBANGUNAN DAERAH JAWA TIMUR, TBK \\
21 & BKSW & PT. BANK QNB KESAWAN, TBK \\
22 & BMAS & PT. BANK MASPION INDONESIA, TBK \\
23 & BMRI & PT. BANK MANDIRI (PERSERO), TBK \\
24 & BNBA & PT. BANK BUMI ARTA, TBK \\
25 & BNGA & PT. BANK CIMB NIAGA, TBK \\
26 & BNII & PT. BANK INTERNASIONAL INDONESIA, TBK \\
27 & BNLI & PT. BANK PERMATA, TBK \\
28 & BSIM & PT. BANK SINARMAS, TBK \\
29 & BSWD & PT. BANK SWADESI, TBK \\
30 & BTPN & PT. BANK TABUNGAN PENSIUNAN NASIONAL, TBK \\
31 & BVIC & PT. BANK VICTORIA INTERNASIONAL, TBK \\
32 & DNAR & PT. BANK DINAR INDONESIA, TBK \\
33 & INPC & PT. BANK ARTHA GRAHA INTERNASIONAL, TBK \\
34 & MAYA & PT. BANK MAYAPADA INTERNATIONAL, TBK \\
35 & MCOR & PT. BANK WINDU KENTJANA INTERNASIONAL, TBK \\
36 & MEGA & PT. BANK MEGA, TBK \\
37 & NAGA & PT. BANK MITRANIAGA, TBK \\
38 & NISP & PT. OCBC NISP \\
39 & NOBU & PT. BANK NATIONALNOBU, TBK \\
40 & PNBN & PT. BANK PAN INDONESIA, TBK \\
41 & PNBS & PT. BANK PANIN SYARIAH, TBK \\
42 & SDRA & PT. BANK HIMPUNAN SAUDARA 1906, TBK \\
\hline
\end{tabular}

Sampel menurut Sugiyono (2011:81) adalah bagian dari jumlah dan karakteristik yang dimiliki oleh populasi tersebut. Pemilihan sampel penelitian ini ditentukan secara purposive sampling, yaitu sampel ditarik sejumlah tertentu dari populasi emiten dengan menggunakan pertimbangan atau kriteria tertentu. Kriteria pemilihan sampel dalam penelitian ini adalah sebagai berikut:(1) Perusahaan Perbankan Konvensional yang listing di Bursa Efek Indonesia ( BEI) sejak tahun 2012-2016. (2) Mempublikasikan laporan keuangan periodik selama periode pengamatan dari tahun 2012 hingga tahun 2016 dengan lengkap. (3) Perusahaan yang tidak memiliki laba negatif (rugi) dari tahun 2012 sampai dengan 2016. (4) Perusahaan yang memiliki data yang lengkap terkait dengan penelitian ini.Berdasarkan kriteria tersebut maka jumlah populasi yang memenuhi kriteria untuk dijadikan sampel dalam penelitian ini berjumlah 11 perusahaan ditunjukkan oleh tabel 3:

Tabel 3

Sampel Bank Konvensional di Bursa Efek Indonesia Periode 2012-2016

\begin{tabular}{ccc}
\hline No & Kode & \multicolumn{1}{c}{ Perusahaan Perbankan Konvensional } \\
\hline 1 & AGRO & PT. BANK RAKYAT INDONESIA AGRONIAGA, TBK \\
2 & BBCA & PT. BANK CENTRAL ASIA, TBK \\
\hline
\end{tabular}




\begin{tabular}{cll}
\hline 3 & BBKP & PT. BANK BUKOPIN, TBK \\
4 & BBNI & PT. BANK NEGARA INDONESIA (PERSERO), TBK \\
5 & BDMN & PT. BANK DANAMON INDONESIA, TBK \\
6 & BJBR & PT. BANK PEMBANGUNAN DAERAH JAWA BARAT DAN \\
& & BANTEN, TBK (BANK BJB) \\
7 & BJTM & PT. BANK PEMBANGUNAN DAERAH JAWA TIMUR, TBK \\
8 & BMRI & PT. BANK MANDIRI (PERSERO), TBK \\
9 & BNII & PT. BANK INTERNASIONAL INDONESIA, TBK \\
10 & BTPN & PT. BANK TABUNGAN PENSIUNAN NASIONAL, TBK \\
11 & NISP & PT. OCBC NISP \\
& & \\
\hline
\end{tabular}

Variabel penelitian adalah suatu atribut atau sifat atau nilai dari orang,objek atau kegiatan yang mempunyai variasi tertentu yang ditetapkan oleh peneliti untuk dipelajari dan kemudian ditarik kesimpulan (Sugiyono, 2011:60). Pada penelitian ini telah ditentukan dua variabel, yaitu variabel terikat (dependent variable) dan variabel bebas (independent variable), sebagai berikut:Variabel Independen (variabel bebas) yaitu variabel yang mempengaruhi nilai variabel dependen (tidak bebas). Suatu variabel digolongkan dalam variabel bebas apabila dalam hubungan dengan variabel lain memiliki fungsi sebagai variabel yang menerangkan variabel lainnya. Hubungan judul yang ditetapkan di atas, maka yang menjadi variabel independen adalah rasio keuangan yang terdiri dari:Capital Adequacy Ratio $\left(X_{I}\right)$, Loan to Deposit Ratio $\left(X_{2}\right)$, danBOPO $\left(X_{3}\right)$.Variabel Dependen (Variabel Terikat) yaitu variabel yang nilainya dipengaruhi oleh variabel independen. Kaitan dengan penelitian di atas, maka yang menjadi variabel dependen adalah Return On Assets (ROA) pada perusahaan industri perbankan Konvensional di Bursa Efek Indonesia periode $2012 \mathrm{~s} / \mathrm{d} 2016$.

\section{Instrumen Penelitian}

Instrumen penelitian variabel Independen yang mempengaruhi variabel Dependen dalam penelitian ini dapat dilihat dari tabel 4 berikut:

Tabel 4

Instrumen Penelitian

\begin{tabular}{llcc}
\hline No & Variabel & \multicolumn{1}{c}{ Indikator } & Sumber \\
\hline & $\begin{array}{l}\text { Capital } \\
\text { adequacy } \\
\text { ratio }(\mathrm{CAR})\end{array}$ & CAR $=\frac{\text { Modal (Modal Inti }+ \text { Modal Pelengkap) }}{\text { Aktiva Tertimbang Menurut Risiko (ATMR) }} \times 100 \%$ & $\begin{array}{c}\text { laporan laba } \\
\text { rugi periode } \\
2012-2016\end{array}$ \\
\hline & $\begin{array}{l}\text { Loan to } \\
\text { deposit ratio } \\
\text { (LDR) }\end{array}$ & LDR $=\frac{\text { Kredit }}{\text { Dana Pihak Ketiga }} \times 100 \%$ & Neraca dan \\
laporan laba \\
rugi periode \\
\end{tabular}


JURNAL ILMU MANAJEMEN UNIVERSITAS TADULAKO

Vol. 5, No. 2, Mei 2019, p. 196 - 210

ISSN : 2443-3578 (On Line) / ISSN : 2443-1850 (Print)

\begin{tabular}{|c|c|c|c|}
\hline 3 & $\begin{array}{l}\text { Operating } \\
\text { expenses to } \\
\text { operating } \\
\text { income } \\
\text { (BOPO) }\end{array}$ & $\mathrm{BOPO}=\frac{\text { Beban Operasional }}{\text { Pendapatan Operasional }} \times 100 \%$ & $\begin{array}{c}\text { Neraca dan } \\
\text { laporan laba } \\
\text { rugi periode } \\
2012-2016\end{array}$ \\
\hline 4 & $\begin{array}{l}\text { Return on } \\
\text { assets } \\
\text { (ROA) }\end{array}$ & $\mathrm{ROA}=\frac{\text { Laba Sebelum Pajak }}{\text { Total Aset }} \times 100 \%$ & $\begin{array}{c}\text { Neraca dan } \\
\text { laporan laba } \\
\text { rugi periode } \\
2012-2016\end{array}$ \\
\hline
\end{tabular}

\section{HASIL DAN PEMBAHASAN}

\section{Hasil Penelitian}

Hasil penelitian terdiri dari pengujian statistik deskriptif dan kemudian pengujian model dalam regresi data panel dengan tiga pendekatan metode alternatif. Pengujian statistik deskriptif bertujuan memberikan gambaran atau deskripsi data yang dilihat dari nilai minimum, nilai maksimum, nilai mean (rata-rata) dan standar deviasi dari masing-masing variabel penelitian yang meliputi variabel CAR, LDR, BOPO dan ROA. Pemodelan dalam menggunakan teknik regresi data panel dapat menggunakan tiga pendekatan metode alternatif dalam pengolahannya. Pendekatan-pendekatan tersebut ialah Common Effect Method, Fixed Effect Method dan Random Effect Method. Sebelum melakukan estimasi model diperlukan pemilihan model terbaik yang akan digunakan untuk mengestimasi data panel. Pemilihan model tersebut melalui beberapa pengujian.Pengujian yang dimaksud adalah uji chow yang digunakan untuk memilih Common Effect Method atau Fixed Effect Method dan Uji hausman digunakan untuk memilih Fixed Effect Method atau Random Effect. Berikut merupakan hasil uji chow:

Tabel 5

Hasil Uji Model Menggunakan Chow Test

\begin{tabular}{lccc}
\hline \hline Effects Test & Statistic & d.f. & Prob. \\
\hline \hline Cross-section F & 45.069033 & $(10,41)$ & 0.0000 \\
\hline \hline
\end{tabular}

Sumber:Hasil output regresi panel data eviews 6

Berdasarkan hasil uji chow pada tabel 5 mengenai pemilihan model antara common effect method dan fixed effect method diperoleh hasil nilai probability pada cross section $F$ memperlihatkan angka bernilai 0,0000 yang berarti signifikan dengan tingkat signifikansi 0,05 . Sehingga keputusan yang diambil pada chow test ini yaitu $\mathrm{H}_{0}$ ditolak dan $\mathrm{H}_{1}$ diterima (Prob $\mathrm{F}<0,05$ ) dengan hipotesis:

$\mathrm{H}_{0}$ :Common effect method

$\mathrm{H}_{1}$ :Fixed effect method

Berdasarkan hasil dari pengujian Chow Test diatas, maka metode pilihan yang terpilih adalah menggunakan Fixed Effect Method dan akan dilakukan uji Hausman Testberikut: 
Tabel 6

Hasil Uji Model Dengan Menggunakan Hausman Test

\begin{tabular}{cccc}
\hline \hline Test Summary & Chi-Sq.Statistic & Chi-Sq. d.f. & Prob. \\
\hline \hline Cross-section Random & 9.126681 & 3 & 0.0277 \\
\hline \hline
\end{tabular}

Sumber: Hasil output regresi panel data eviews 6

Tabel di atas memperlihatkan pemilihan model antara random effect method dengan fixed effect method diperoleh hasil nilai probability pada Cross-section Random memperlihatkan angka bernilai 0,0277 yang berarti signifikan dengan tingkat signifikansi 0,05. Maka keputusan pada uji model hausman test ini yaitu $\mathrm{H}_{0}$ ditolak dan $\mathrm{H}_{1}$ diterima.

$\mathrm{H}_{0}:$ Random Effect Method

$\mathrm{H}_{1}$ :Fixed Effect Method

Berdasarkan hasil dari pengujian hausman test di atas, maka metode yang terpilih adalah menggunakan fixed effect method. Data chow test dan hausman test di atas menunjukkan bahwa fixed effect method adalah model dengan hasil paling baik dalam penelitian ini.

\section{Analisis Regresi Data Panel}

Hipotesis pertama menyatakan bahwa variabel independen mempunyai pengaruh secara serempak terhadap variabel dependen pada perusahaan Perbankan Konvensional di Bursa Efek Indonesia.Hipotesis kedua menyatakan variabel independen mempunyai pengaruh secara parsial terhadap variabel dependen. Hasil perhitungan regresi data panel dari penelitian ini untuk hipotesis pertama dan kedua dapat dilihat pada tabel 7 berikut ini:

Tabel 7

Hasil Regresi Data Panel

\begin{tabular}{lllll}
\hline \multicolumn{1}{c}{$\begin{array}{c}\text { Variabel } \\
\text { Dependen (Y) }\end{array}$} & $\begin{array}{l}\text { Variabel } \\
\text { Independen }\end{array}$ & Koefisien & T hitung & Sig. \\
\hline \multirow{5}{*}{ ROA } & $\begin{array}{l}\text { Capital Adequacy } \\
\text { Ratio (CAR) }\end{array}$ & -0.002666 & -0.173118 & $0.8634>0.05$ \\
\cline { 2 - 5 } & $\begin{array}{l}\text { Loan to Deposit Ratio } \\
\text { (LDR) }\end{array}$ & -0.002749 & -0.907894 & $0.3692>0.05$ \\
& $\begin{array}{l}\text { Biaya Operasional } \\
\text { Pendapatan }\end{array}$ & -0.018201 & -3.260411 & $0.0022<0.05$ \\
& Operasional (BOPO) & & & \\
\hline Constanta & & 0.038743 & F Hitung & 47.06086 \\
\hline R-Squared & & 0.937193 & F tabel & 2,79 \\
\hline
\end{tabular}


JURNAL ILMU MANAJEMEN UNIVERSITAS TADULAKO

Vol. 5, No. 2, Mei 2019, p. 196 - 210

ISSN : 2443-3578 (On Line) / ISSN : 2443-1850 (Print)

\begin{tabular}{llll}
\hline Adjusted R-Squared & 0.917278 & Sig & 0.000 \\
\hline & t.tabel \\
\hline
\end{tabular}

Sumber:Hasil output regresi panel data eviews 6

Berdasarkan hasil perhitungan pada tabel 7 dapat dirumuskan persamaan regresi data panel dari penelitian ini sebagai berikut:

$Y=0.038743+(-0.002666(X 1))+(-0.002749(X 2))+(-0.018201(X 3))+e$

Variabel Capital Adequacy Ratio $\left(\mathrm{X}_{1}\right)$ mempunyai koefisien sebesar -0.002666, hal ini berarti setiap perubahan (penurunan) variabel $\mathrm{X}_{1}$ sebesar 1 persen, maka Return On Assets akan menurun sebesar 0.002666. Variabel Loan to Deposit Ratio $\left(\mathrm{X}_{2}\right)$ mempunyai koefisien sebesar -0.002749 , hal ini berarti setiap perubahan variabel $\mathrm{X}_{2}$ sebesar 1 persen, Return On Assets akan menurun sebesar -0.002749 . Variabel $\mathrm{BOPO}\left(\mathrm{X}_{3}\right)$ mempunyai koefisien sebesar -0.018201 , hal ini berarti setiap perubahan variabel $\mathrm{X}_{3}$ sebesar 1 persen, Return On Assets akan menurun sebesar -0.018201.

\section{Pengujian Serempak ( Uji F)}

Uji F atau uji simultan untuk menguji pengaruh variabel independen secara simultan atau serempak. Apabila tingkat signifikansi variabel independen terhadap variabel dependen dibawah 0,05 maka dikatakan bahwa variabel tersebut berpengaruh signifikan. Berikut hasil uji simultan atau uji $\mathrm{F}$ dapat dilihat pada tabel 8:

Tabel 8

Hasil Uji F

\begin{tabular}{llll}
\hline \hline R-squared & 0.937193 & Mean dependent var & 0.032917 \\
Adjusted R-squared & 0.917278 & S.D. dependent var & 0.016427 \\
S.E. of regression & 0.003897 & Sum squared resid & 0.000623 \\
F-statistic & 47.06086 & Durbin-Watson stat & 1.832811 \\
Prob(F-statistic) & 0.000000 & & \\
\hline
\end{tabular}

Sumber:Hasil output regresi panel data eviews 6

Kriteria pengujian hipotesis yang pertama dalam penelitian ini adalah dengan membandingkan $\mathrm{F}_{\text {hitung }}$ (47.06086) $>F_{\text {tabel }}(\mathbf{2 . 7 9})$ dengan taraf signifikansi $(\mathbf{0 . 0 0 0 0 0 0}<\mathbf{0 . 0 5})$ maka kesimpulannya $\mathrm{H}_{0}$ ditolak dan $\mathrm{H}_{1}$ diterima. Dapat diartikan bahwa seluruh variabel independen yaitu Capital Adequacy Ratio, Loan to Deposit Ratio danBOPOyang dimasukkan dalam model secara simultan atau serempak berpengaruh signifikan terhadap variabel dependen yaitu Return On Assets. Maka dari pernyataan diatas disimpulkan bahwa dalam penelitian ini hipotesis pertama yang menyatakan bahwa CAR, LDR dan BOPO secara 
bersama-sama berpengaruh signifikan terhadap ROA Perbankan Konvensionalyang terdaftar di Bursa Efek Indonesia.

\section{Uji Parsial ( Uji t)}

Uji t atau uji parsial merupakan pengujian terhadap pengaruh masing-masing variabel independen yaitu Capital Adequacy Ratio, Loan to Deposit Ratio danBOPO terhadap variabel dependen yaitu Return On Assets. Uji parsial pada fungsi estimasi bertujuan untuk membuat kesimpulan mengenai pengaruh masingmasing variabel independen terhadap variabel dependen.Berikut merupakan hasil uji t atau uji parsial.

\section{Tabel 9}

Hasil Uji Parsial (t Test)

\begin{tabular}{crrrr}
\hline \hline Variable & Coefficient & Std. Error & t-Statistic & Prob. \\
\hline \hline C & 0.038743 & 0.005628 & 6.884282 & 0.0000 \\
CAR & -0.002666 & 0.015400 & -0.173118 & 0.8634 \\
LDR & -0.002749 & 0.003027 & -0.907894 & 0.3692 \\
BOPO & -0.018201 & 0.005582 & -3.260411 & 0.0022 \\
\hline \hline
\end{tabular}

Sumber : Hasil output regresi panel data eviews 6

Hasil uji t yang terlihat pada tabel 9diperoleh:(a) Pengujian hubungan variabel CAR terhadap ROA adalah dengan melihat taraf signifikansi $(0.863>0.05)$ dan nilai koefisien -0.002666 . Hasil tersebut menunjukkan bahwa Variabel CAR tidak berpengaruh terhadap ROA. Maka dari pernyataan diatas disimpulkan bahwa hipotesis kedua menyatakan variabel Capital Adequacy Ratio secara parsial tidak berpengaruh terhadap Return On Assets Perbankan Konvensionalyang terdaftar di Bursa Efek Indonesia sesuai dengan hasil uji $t$ yang dilakukan. (b) Pengujian tentang berpengaruh atau tidaknya variabel Loan to Deposit Ratio terhadap Return On Assets adalah dengan melihat taraf signifikansi $(0.3692>0.05)$ dan nilai koefisien -0.002749. Taraf signifikansi memberikan makna bahwa Loan to Deposit Ratio memiliki pengaruh dan tidak signifikan terhadap Return On Assets dapat dilihat dari nilai probability yang memiliki nilai lebih dari 0,05 memberikan makna bahwa variabel Loan to Deposit Ratio memberikan pengaruh yang tidak signifikan terhadap Return On Assets. Maka dari pernyataan diatas disimpulkan bahwa hipotesis kedua yang menyatakan variabel Loan to Deposit Ratio secara parsial berpengaruh negatif dan tidak signifikan terhadap Return On Assets Perbankan Konvensionalyang terdaftar di Bursa Efek Indonesia sesuai dengan hasil uji $t$ yang dilakukan. (c) Pengujian tentang berpengaruh atau tidaknya variabel BOPO terhadap Return On Assets adalah dengan melihat taraf signifikansi $(0.0022>0.05)$ dan nilai koefisien -0.018201. Taraf signifikansi memberikan makna bahwa BOPOmemiliki pengaruh negatif dan signifikan terhadap Return On Assets dapat dilihat dari nilai probability yang memiliki nilai kurang dari 0,05 memberikan makna bahwa variabel BOPOmemberikan pengaruh negatif dan signifikan terhadap Return On Assets. Maka dari pernyataan diatas disimpulkan bahwa hipotesis kedua yang menyatakan variabel BOPOsecara parsial berpengaruh signifikan terhadap Return On Assets Perbankan Konvensionalyang terdaftar di Bursa Efek Indonesia sesuai dengan hasil uji $t$ yang dilakukan. 


\section{Koefisien Determinasi $\left(\mathbf{R}^{2}\right)$}

Persentase pengaruh semua variabel independen terhadap variabel dependen ditunjukkan oleh besarnya koefisien determinasi yang dapat dilihat dari nilai $R$ Squared.Apabila $R$ Squared mendekati 1, maka dapat dikatakan bahwa variabel independen yang digunakan dapat menjelaskan variabel dependen secara keseluruhan, begitu pula sebaliknya.Berikut ini merupakan hasil $R$ Squared.

Tabel 10

Nilai $R$ Squared

\begin{tabular}{llll}
\hline \hline R-squared & $\mathbf{0 . 9 3 7 1 9 3}$ & Mean dependent var & 0.032917 \\
Adjusted R-squared & 0.917278 & S.D. dependent var & 0.016427 \\
S.E. of regression & 0.003897 & Sum squared resid & 0.000623 \\
F-statistic & 47.06086 & Durbin-Watson stat & 1.832811 \\
Prob(F-statistic) & 0.000000 & & \\
\hline \hline
\end{tabular}

Sumber: Hasil output regresi panel data eviews 6

Hasil perhitungan yang diperoleh besarnya koefisien determinasi yang disesuaikan ( $R$ Squared) adalah 0.937193. Artinya pengaruh semua variabel independen ( $C A R, L D R$ dan BOPO)terhadap perubahan nilai variabel dependen ( $R O A$ ) adalah sebesar $93 \%$ dan sisanya $7 \%$ dipengaruhi oleh variabel lain selain variabel independen yang digunakan dalam regresi data panel seperti manajemen perusahaan, faktor eksternal perusahaan antara lain peraturan pemerintah, tingkat suku bunga, inflasi, nilai tukar rupiah, kondisi politik dalam negara dan kondisi perekonomian yang tidak stabil.

\section{Pembahasan}

Modal merupakan sumber dana pihak pertama, yaitu sejumlah dana yang diinvestasikan oleh pemilik untuk pendirian suatu bank. Jika bank tersebut sudah beroperasi maka modal merupakan salah satu faktor yang sangat penting bagi pengembangan usaha dan menampung risiko kerugian. Agar perbankan dapat berkembang secara sehat dan mampu bersaing maka permodalan bank harus senantiasa mengikuti ukuran yang berlaku yaitu CAR berada diatas $8 \%$.Tingkat modal yang tinggi akan meningkatkan cadangan kas yang dapat digunakan untuk memperluas kreditnya, sehingga tingkat solvabilitas yang tinggi akan membuka peluang yang lebih besar bagi bank untuk meningkatkan profitabilitasnya. Sebaliknya bank yang tingkat solvabilitasnya rendah akan mengurangi kemampuan bank untuk meningkatkan profitabilitasnya, bahkan dapat mengurangi kepercayaan masyarakat, sehingga akan berpengaruh buruk terhadap kelangsungan usahanya.

Pada awalnya peneliti beranggapan bahwa Capital Adequacy Ratio akan berpengaruh positif terhadap Return On Assets, namun hal ini tidak sesuai dengan hasil penelitian yang didapatkan. Hasil Penelitian menunjukkan bahwa Capital Adequacy Ratio tidak berpengaruh terhadap Return On Assets. Tidak berpengaruhnya Capital Adequacy Ratio terhadap Return On Assets disebabkan karena bank-bank yang beroperasi tidak mengoptimalkan modal yang ada, Hal ini ini terjadi karena peraturan Bank Indonesia yang mensyaratkan CAR minimal 8\% mengakibatkan bank-bank selalu berusaha menjaga agar CAR yang 
dimilikinya sesuai dengan ketentuan. Bank yang memiliki rasio modal diatas $8 \%$ pun belum bisa menghasilkan profitabilitas yang tinggi.

Tingginya rasio LDR mengindikasikan bahwa dana deposito dari masyarakat yang tertanam dalam pinjaman semakin besar. Semakin besarnya penyaluran kredit maka dalam kondisi yang normal akan menyebabkan laba yang meningkat. Laba ini berasal dari penerimaan bunga pinjaman dari kredit yang disalurkan. Tetapi jika bank mengurangi jumlah kredit yang telah dikucurkan (mengubah aktiva kredit menjadi aktiva yang kurang produktif), maka kemampuan bank untuk memperoleh penghasilan (terutama penghasilan yang berasal dari bunga pinjaman) akan turun. Penurunan ini akan berakibat menurunnya ROA.

Berdasarkan hasil outputeviews, Penelitian ini menunjukkan bahwa LDR cenderung berpengaruh negatif dan tidak signifikan terhadap ROA. Hal ini disebabkan karena tingginya LDR tidak dapat mempengaruhi kenaikan ROA meski nilai LDR dalam kondisi sehat yang ditunjukkan Hasil analisis deskriptif dimana rata-rata nilai LDR adalah $92,18 \%$ selama 5 tahun periode penelitian. Kondisi ini menggambarkan bahwa kinerja bank pada umumnya tidak efisien, sehingga tidak dapat memaksimalkan nilai pendapatan dari dana yang dipinjamkan kepada masyarakat. Ketidakefisienan ini bisa disebabkan karena banyak kredit yang mengalami kegagalan, sehingga menambah beban bagi bank.

Hubungan yang negatif antara variabel BOPO dengan ROA sesuai dengan teori yang dikemukakan Siamat (1999), tingkat BOPO yang menurun menunjukkan semakin tinggi efisiensi operasional yang dicapai perusahaan, hal ini berarti semakin efisien aktiva bank dalam menghasilkan keuntungan.Peningkatan biaya operasional bank yang tidak diikuti dengan peningkatan pendapatan operasional akan berakibat berkurangnya laba bersih sehingga akan menurunkan profitabilitas (ROA). Tingginya biaya yang dikeluarkan dalam menghasilkan keuntungan yang dicapai perusahaan, maka akan mengakibatkan rendahnya efisiensi operasional bank dan selanjutnya berpengaruh terhadap tingkat profitabilitas yang semakin menurun. Tetapi jika penurunan biaya operasional bank diikuti dengan kenaikan pendapatan operasional, maka akan mempengaruhi pula kenaikan ROA.

Hasil penelitian ini menunjukkan bahwa BOPO berpengaruh negatif dan signifikan terhadap ROA dengan nilai signifikansi 0.0022. Ini dikarenakan nilai rata-rata BOPO selama periode penelitian yaitu 65\% dibawah standar maksimal BOPO menurut Bank Indonesia yaitu 93,52\%. Semakin rendah nilai BOPO maka semakin tinggi Profitabilitasnya karena menggambarkan tingginya Pendapatan Operasional dibandingkan dengan Beban Operasional dimana Selisihnya merupakan keuntungan bagi bank.

\section{KESIMPULAN DAN SARAN \\ Kesimpulan}

Berdasarkan hasil pengujian data, pembahasan dan pengujian hipotesis yang telah dilakukan, maka dapat disimpulkan sebagai berikut:(1) Secara Serempak, CAR (Capital Adequacy Ratio), LDR (Loan to Deposit Ratio) dan BOPO (Biaya Operasional Pendapatan Operasional) berpengaruh secara signifikan terhadap ROA (Return On Assets) perusahaan Perbankan Konvensional di BEI. (2) Capital Adequacy Ratio (CAR) berpengaruh tidak signifikan terhadap Return On Assets (ROA) perusahaan Perbankan Konvensional di BEI. (3) Loan to Deposit Ratio (LDR) berpengaruh tidak signifikan terhadap Return On 
Assets (ROA) perusahaan Perbankan Konvensional di BEI. (4) Biaya Operasional Pendapatan Operasional (BOPO) berpengaruh signifikan terhadap Return On Assets (ROA) perusahaan Perbankan Konvensional di BEI.

\section{Saran}

Berdasarkan hasil penelitian diatas dapat disarankan sebagai berikut:(1) Saran penulis berdasarkan temuan hasil penelitian maka untuk meningkatkan pendapatan bank-bank di BEI dengan modal, dana pihak ketiga dan efisiensi operasional dimana modal usaha yang besar tidak hanya menganggur untuk menanggulangi kemungkinan risiko yang dihadapi bank tapi juga dioptimalkan dengan pengembangan usaha, kemudian dana pihak ketiga dapat menjalankan fungsi intermediasi yaitu dengan menyalurkan kredit dengan bunga rendah agar lebih kompetitif dengan prinsip kehati-hatian serta selalu menjaga efisiensi dalam hal pengeluaran biaya. (2) Hasil juga menunjukkan variabel independen tidak dapat mewakili kondisi perusahaan perbankan secara menyeluruh dikarenakan kurangnya 4\% yang mempengaruhi ROA dan hanya satu variabel yang signfikan menunjukkan hubungan secara parsial yaitu BOPO terhadap ROA. Untuk peneliti selanjutnya disarankan agar dapat menambah variabel-variabel lainnya serta dengan jumlah bank yang lebih besar.

\section{REFERENSI}

Ambo, Aman. 2013. Analisis Kinerja Keuangan Dengan Metode Camel Pada Bank Umum Swasta Nasional Devisa di Indonesia Tahun 2007 - 2011. Skripsi.UNHAS Makassar.

Dahlan Siamat, 1999. Bank dan Lembaga Keuangan. Edisi Kedua, Jakarta: Universitas Indonesia.

Dendawijaya, Lukman, 2003. Manajemen Perbankan. Jakarta: Ghalia Indonesia. , 2009.Manajemen Perbankan. Edisi Kedua. Jakarta: Ghalia Indonesia.

Fahmi, Irham,2011. Analisis kinerja keuangan.Bandung: Alfabeta. , 2012. Pengantar Manajemen Keuangan. Bandung: Alfabeta.

Ikatan Akuntan Indonesia, 2009.Standar Akuntansi Keuangan. Jakarta: Salemba Empat Kasmir, 2008.Analisa Laporan Keuangan. Jakarta: Bumi Aksara. ,2014. Manajemen Perbankan. Edisi Revisi. Cetakan Ke-12.Depok: Raja Grafindo Persada. Kuncoro, Mudrajad, 2009. Metode Riset Untuk Bisnis dan Ekonomi. Edisi 3.Jakarta: Erlangga. Sugiyono. 2011. Metode Penelitian Kuantitatif, Kualitatif Dan R\&D. Bandung: Alfabeta. 